\title{
ВОПРОСЫ РАЗВИТИЯ ТУРИЗМА СТАРШЕГО ПОКОЛЕНИЯ В АЛТАЙСКОМ КРАЕ
}

\begin{abstract}
Аннотация. В статье рассматриваются актуальные вопросы и тенденции развития туризма старшего поколения в Алтайском крае. Автор анализирует текущее положение, возможности и перспективы организации туристических маршрутов для возрастных путешественников на территории Алтайского края. Приводятся примеры международного опыта в развитии туризма старшего поколения, выявляются особенности предпочтений данной категории путешественников, предлагается ряд мероприятий и методических рекомендаций для создания адаптированных туристических продуктов для граждан третьего возраста.
\end{abstract}

Ключевые слова: внутренний туризм, туризм старшего поколения, третий возраст, туристский продукт, «senior-friendly tourism», туризм в Алтайском крае, возрастные путешественники, экскурсионное обслуживание.

Стимулирование развития внутреннего туризма в России становится одной из приоритетных задач государственной политики в туристской сфере. По поручению правительства Российской Федерации Федеральное агентство по туризму (Ростуризм) ведет работу над формированием Национального проекта «Туризм и индустрия гостеприимства». 3 марта 2021 премьер-министр Российской Федерации Михаил Мишустин в рамках рабочей поездки по Сибирскому федеральному округу провел совещание по вопросам развития туризма в Республике Алтай и Алтайском крае. Глава правительства отметил огромный туристический потенциал территорий и обозначил основные направления работы. В ближайшем будущем власти края и республики Алтай должны проработать меры по созданию условий для активного развития разнообразных видов внутреннего туризма и снятию инфраструктурных ограничений.

Разработка туристического продукта для отдыхающих разных возрастов становится стратегической задачей специалистов сферы туризма. Официальные статистические данные показывают рост туристов третьего возраста среди групп самостоятельных путешественников. По данным Росстата, к 2030 году число пенсионеров в России увеличится до $28,3 \%$ (32,2 млн). Такие изменения социально-демографической ситуации в российском обществе уже в ближайшем будущем могут отразиться на туристическом рынке. Предложения по организации отдыха для туристов категории «55+» станут все более востребованными.

Туристической отрасли Алтайского края важно не упустить время и приступить к реше- нию вопросов создания необходимых условий для путешественников третьего возраста. Через несколько лет на рынке туристических услуг может появится новое поколение пенсионеров и предпенсионеров, имеющих опыт путешествий за границей, которые станут более требовательными заказчиками и потребителями турпродуктов Алтайского края. К этому времени необходимо провести работу по персонализации туристических предложений на Алтае для людей старшего поколения. Разнообразие туристских ресурсов Алтайского края позволяет развивать культурно-познавательный, лечебнооздоровительный, сельский, рыболовныйохотничий, событийный, гастрономический туризм. Каждое из этих направлений необходимо адаптировать с учетом предпочтений и спроса потребителей старшего возраста.

Разработка туристских предложений должна быть основана на особенностях и специфике организации досуга для этой категории путешественников. В настоящее время путешествует не более $12 \%$ из числа граждан Российской Федерации старшего возраста. Такие невысокие цифры обусловлены, в первую очередь, финансовыми возможностями пенсионеров, небольшим количеством специализированных предложений от туроператоров, малоприспособленными условиями размещения и возрастными стереотипами. Меняющиеся демографические и социальные условия все больше стимулируют отечественную туристическую отрасль обратить внимание на целевую аудиторию «55+». В российских условиях становятся актуальными зарубежные исследования и опыт по разработке, производству, маркетингу и потреблению 
туристских продуктов представителями третьего возраста, проектирование туристского развития территорий [1].

Изучение международного опыта развития туризма старшего поколения дает понимание особенностей предпочтений данной категории путешественников. К примеру, европейские пенсионеры предпочитают путешествовать несколько раз в год, выбирая продолжительные туры, межсезонные выгодные предложения и железнодорожный транспорт. В сравнении к другими возрастными категориями путешественников, старшее поколение туристов характеризуется наличием свободного времени, проявляет большую заинтересованность в посещении мастер-классов, познавательных лекций, приобретает дополнительные услуги культурнопознавательного характера. Возрастные туристы зачастую привержены выбранной туристской дестинации и совершают повторные путешествия. Как показывают исследования, чем старше турист, тем больше его возраст оказывает влияние на повторное посещение дестинации и на увеличение продолжительности тура по сравнению с продолжительностью путешествия более молодых лиц [2].

Развитие туризма старшего поколения - это одна из мер по повышению качества жизни пожилых членов общества. Выполняя социальную функцию, туризм для пожилых граждан обеспечивает этой возрастной группе большую общественную интеграцию, способствует активному долголетию и оздоровлению. Путешествие уникальное средство реабилитации, расширения круга общения по интересам, которое помогает получить уверенную и эффективную жизненную поддержку, необходимую человеку старшего поколения [3]. Таким образом, появление круглогодичных туристских маршрутов по территории Алтайского края, адаптированных для возрастных граждан, имеет широкое социальное значение и отвечает задачам Федерального проекта «Старшее поколение» на 2019-2024 годы, направленного на создание программы системной поддержки и повышения качества жизни этой категории граждан.

В 2016 году по заказу Министерства культуры Российской Федерации был разработан каталог культурно-исторических маршрутов России для организации туризма людей пожилого возраста. В каталоге собрано 60 маршрутов из 28 регионов страны и предложены виды туризма, учитывающие интересы и возможности людей пенсионного возраста (туризм архитектурной культуры, исторический туризм, туризм литературы и искусств, туризм тематических парков, туризм городской среды и культуры, сельский туризм, музейный туризм). Алтайский край представлен в каталоге всего одним маршрутом «Малое Золотое кольцо Алтая», в то время, как Санкт-Петербург и Ленинградская область, Республика Удмуртия, Владимирская область и Свердловская область представлены 4-5 маршрутами.

Маршрут по Алтайскому краю, предложенный Минкультуры РФ, включает в себя следующие туристические объекты показа - Бийский краеведческий музей им. В. В. Бианки, Музей истории Алтайской духовной миссии (г. Бийск), Всероссийский мемориальный музей им. В. М. Шукшина (с. Сростки), пасека семьи Бедаревых (с. Красногорское), экономическая зона туристско-рекреационного типа «Бирюзовая Катунь» и озеро Ая, комплекс «Холмогорье» (с. Алтайское), гора Церковка, Белокурихинский городской музей им. С. И. Гуляева (г. Белокуриха), туристско-рекреационный комплекс «Сибирское подворье» (с. Новотырышкино). Предлагаемая продолжительность тура 3-5 дней. Такое организованное путешествие в рамках маршрута «Малое Золотое кольцо Алтая» доступно к осуществлению и может быть интересно пожилым гражданам со всей страны, но для того, чтобы повысить количество таких маршрутов на территории Алтайского края и их востребованность, необходимо провести ряд целенаправленных исследований и мероприятий. К таким мероприятиям можно отнести выявление привлекательных с точки зрения возрастных путешественников туристических объектов Алтайского края, разработку туристских маршрутов, тестирование одного из таких маршрутов с помощью фокус-группы, состоящей из жителей региона. Результатам данных мероприятий может стать расширение выбора туристских продуктов Алтайских туркомпаний для граждан старшего поколения и появление практических рекомендаций для объектов туристской инфраструктуры края.

Учитывая интересы и возможности туристов старшего поколения, необходимо разработать варианты маршрутов небольшой продолжительностью, организовать безопасность и комфорт передвижения, размещения и питания, и адаптировать к предпочтениям возрастных путешественников экскурсионное обслуживание.

Путешествия пожилых туристов должны быть максимально физически комфортными. Учитывая специфику Алтайского края, оптимальным вариантом тура для туристов «55+» можно назвать автобусный тур. При выборе 
транспорта, желательно отдавать предпочтение просторным моделям автобусов, с удобными сидениями, телевизором и кондиционером. Во время переездов по маршруту следует продумать развлекательную программу. Подходящим развлечением возрастной публики может оказаться автобусное караоке, поэтому выбирая автобус, необходимо учесть наличие качественной звуковой системы, особенно для дальних переездов. Необходимым условием организации передвижения возрастной группы являются регулярные и частые санитарные остановки в пути. Экскурсионный маршрут не должен включать долгих переходов и утомительных переездов. В пеших маршрутах должны отсутствовать значительные перепады высоты и передвижение по сложно-пересечённой местности. Рекомендованная длительность пешего маршрута для пожилых туристов - не более одного часа, при благоприятном температурном режиме, с предоставлением периодического отдыха.

Немаловажным фактором в организации туризма для возрастных путешественников является психологический комфорт. Наличие круга единомышленников и интересного коллектива повысит эмоционально-психологическое благополучие возрастных туристов и окажет позитивное влияние на восприятие путешествия.

Следует учитывать финансовые возможности и предпочтения людей старшего поколения при выборе времени организации тура и его наполнения экскурсионными объектами. Межсезонье является оптимальным периодом для путешествия пожилых граждан, не привязанных к срокам отпусков, и имеющих возможность воспользоваться значительными скидками в период спада туристического потока. Экскурсионное обслуживание должно быть адаптировано к предпочтениям данной категории путешественников. Туристы старшего возраста ценят неспешные культурнопознавательные прогулки, исторические экскурсии с посещением музеев, мемориалов, мероприятия с историческими реконструкциями, паломнические туры, ностальгические туры (посещение объектов, с которыми связаны воспоминания и события из жизни) посещение могил предков, фестивали бардовской песни и др. Событийный туризм для возрастных граждан на Алтае может включать следующие традиционные мероприятия: «Шукшинские дни на Алтае», фестиваль «Сибирская масленица», фестиваль зимней рыбалки «ЛедОК», праздник «Цветение маральника», литературный фести- валь Роберта Рождественского, фольклорный фестиваль «Троицкие гуляния», гастрономический фестиваль «Ах!Фест», «Всэ будэ смачно!» и многие другие.

Устойчивый спрос среди туристов старшего поколения показывает санаторно-курортный туризм. Этот вид туристических услуг представлен в Алтайском крае санаториями г. Белокурихи и г. Барнаула. При разработке туристского продукта для данной категории граждан очень важно включать в пакет услуг различные дополнительные лечебнооздоровительные мероприятия (посещение фито-салонов, горячих источников, спелеологических кабинетов и других мест, которые могут предоставить туристам третьего возраста возможность поправить здоровье и омолодиться).

Путешественникам старшего возраста следует предлагать систему питания «все включено», при которой не нужно совершать дополнительные траты. При выборе варианта размещения следует учитывать следующие факторы: наличие номеров на первом/втором этаже, либо наличие лифта, отсутствие шума в вечернее и ночное время, удобные постельные места, «дружественный к пожилым людям» (seniorfriendly) персонал и др. Объекты размещения должны соответствовать критериям доступности, чтобы быть безопасными и комфортными для пожилых людей. Существует международная практика подбора объектов размещения для туристов старшего поколения. Система классификации объектов размещения ACCESSIBILITY PASS занимается определением уровня доступности отелей на основе изучения инфраструктуры, услуг и навыков персонала [4]. Отбор объектов Алтайского края, отвечающих критериям комфортной и безопасной среды с учётом особенностей старшего возраста можно провести путем тестирования на фокус группе. Владельцам объектов туристской индустрии на территории края, планирующим улучишь условия размещения пожилых туристов рекомендуется оборудовать территории аудиовизуальной информационной системой, предусматривающей наличие звуковых сообщений и информационных табло.

Таким образом, для появления в Алтайском крае туристических продуктов, рассчитанных на старшее поколение, следует развивать условия размещения, питания, уровня транспортного и экскурсионного обслуживания с учетом предпочтений и нужд данной категории путешественников. Прогнозируемое увеличение числа возрастных туристов должно подтолкнуть туристический сектор Алтайского края к повышению 
уровня сервиса и качества оказываемых услуг. Изучение вопросов появления новых и развития имеющихся туристских маршрутов для категории путешественников «55+» должно стать предметом постоянного внимания со стороны туристских фирм и организаций Алтайского края.

Список литературы

1. Илькевич С. В. Перспективы туризма старшего возраста в контексте пенсионной реформы в России. Стратегические решения и риск-менеджмент. 2018. № 4. С. 66-71.
2. Alen E., Nicolau J. L., Losada N., Determinant factors of senior tourists' length of stay. Annals of Tourism Research. 2014. Vol. 49. P. 19-32.

3. Досуг граждан старшего поколения. URL: $\quad$ http://government.ru/docs/all/105372/? page $=2(12.03 .21)$.

4. Age Platform Europe. Global certification scheme senior-friendly hotels. URL: https:/www.age-platform.eu/good-practice/globalcertification-scheme-senior-friendly-hotels-friendly (12.03.21).

УДК 069(571.53):39+291.71: 351.852.14

DOI: $10.32340 / 2514-772 X-2021-1-59-62$

В. В. Тихонов,

кандидат культурологии

Архитектурно-этнографический музей «Тальцы» (Иркутск, Россия) talci@irk.ru

\section{АУТЕНТИЧНАЯ РЕКОНСТРУКЦИЯ БУРЯТСКОГО МИССИОНЕРСКОГО СТАНА В МУЗЕЕ «ТАЛЬЦЫ» КАК ОДНОГО ИЗ ОБРАЗОВАТЕЛЬНЫХ УЧРЕЖДЕНИЙ ПРОШЛОГО}

Аннотация: в рамках обеспечения сохранения исторической памяти рассматривается перспектива аутентичного воссоздания на основе элементов оригиналов и новоделов бурятского православного миссионерского стана в экспозиционном пространстве Архитектурно-этнографического музея «Тальцы». Анализируются предпосылки возникновения бурятских православных миссионерских станов, хронология их создания, инфраструктура наполнения и их роль в системе образовательных процессов в регионе, в особенности по отношению к коренной народности - бурятам. Предлагается к рассмотрению широкой общественности уже реализуемая концепция обобщенной модели бурятского православного миссионерского стана конца XIX в. в музейном пространстве.

Ключевые слова: миссионерский стан, улус-зимник, юрта, буряты, инородиы, экспозиция, музеефикачия.

Освоение территории Предбайкалья русскими первопроходцами началось со второй четверти XVII в. Вместе с казаками в движении на восток участвовало и православное духовенство. В первом Илимском остроге (1647 г.) уже стояла изба черного монаха [1, с. 38]. В 1681 г. православная миссия в Предбайкалье состояла из 12 монахов со старшим у них игуменом Феодосием. К 1851 г. ситуация с православием в Предбайкалье сложилась таким образом, что доля православного населения среди коренных жителей, в основном предбайкальских (западных) бурят, составляла только 68,4 \% [2, с. 104], что было самым низким показателем среди соседних регионов. Остальные проценты составляли шаманисты и отчасти ламаисты.

Середина XIX в. в регионе обозначилась тем, что миссионерская деятельность среди коренного населения усилилась. Главными миссионерами стали православные священники и в значительной меньшей степени представители ламаистской конфессии, для которых в их деятельности властями создавались искусственные препятствия. С целью интенсификации православной миссионерской деятельности в 1861 г. была учреждена Иркутская православная миссия. Благодаря ей уже в 1863 г. появилось пять миссионеров, преподававших среди инородцев (бурят) [3, с. 196]. Одним из них стал инородец протоирей Николай Нилович Доржаев - западный бурят, перешедший в православие из ламаистов. Именно с 60-х гг. XIX в. в Предбайкалье появляются первые миссионерские станы среди инородцев. К началу Первой мировой войны их было в регионе 26.

Православные миссионерские станы располагались непосредственно в бурятских улусах или, редко, вблизи от них, не далее 4 км. Это объяснялось тем, что миссионер часто отлучался по делам епархии или ездил по улусам с миссионер- 